Journal homepage: www.aesacademy.org

\title{
Assessment of soil and water quality as affected by herbicide application in the rice field of Bangladesh
}

\author{
Md. Rashedur Rahman ${ }^{1^{*}}$ (D) , Iffat Ara Mahzabin² and Md. Tofazzal Hossain ${ }^{3}$ \\ ${ }^{1}$ Department of Agronomy, Bangladesh Agricultural University, Mymensingh-2202, BANGLADESH \\ ${ }^{2}$ Department of Agricultural Extension Education, Bangladesh Agricultural University, Mymensingh - 2202, BANGLADESH \\ ${ }^{3}$ Department of Microbiology and Hygiene, Bangladesh Agricultural University, Mymensingh - 2202, BANGLADESH \\ *Corresponding author's E-mail: rashedagron@bau.edu.bd
}

\section{ARTICLE HISTORY}

Received: 25 May 2019

Revised received: 31 May 2019

Accepted: 02 June 2019

\section{Keywords}

Bangladesh

Herbicides

Microbial activity

Rice field

Soil and water quality

\begin{abstract}
Weed is a vital constraint for crop especially rice cultivation. Among several techniques herbicidal weed control is thought to be efficient and cost effective method. But herbicide may change soil or water quality in rice field. Taking this into consideration a study was conducted to assess soil and water quality in herbicide applied rice field. The study was conducted in two phases. In first phase a list of herbicide was made according to the uses by the local farmers of Mymensingh district. It was found that among the herbicides wide used two herbicides were i. Laser (Pyrazosulphuron ethyl-10 WP) and ii. Changer (Acetachlor-14\% + Bensulfuron methyl4\%). In the second phase, an experiment was conducted at Agronomy Field Laboratory, Bangladesh Agricultural University, Mymensingh considering these two herbicides. It was found that the application of herbicide in the rice field did not change the nutrient content in the soil or water of rice field. But herbicide significantly reduced the microbial activity and increased the chlorine content (In case of herbicide 2 i.e. Acetachlor-14\% + Bensulfuron methyl-4\%) in both soil and water of rice field. Therefore, it can be concluded that though the nutrient content of the soil of rice field is not significantly affected by herbicide application but the presence of high amount of $\mathrm{Cl}$ content in the rice field may cause burning injury of rice leaf at the early stages of its growth which could affect the yield of rice.
\end{abstract}

(C)2019 Agriculture and Environmental Science Academy

Citation of this article: Rahman, M.R., Mahzabin, I.A. and Hossain, M.T. (2019). Assessment of soil and water quality as affected by herbicide application in the rice field of Bangladesh. Archives of Agriculture and Environmental Science, 4 (2): 224-229, https://dx.doi.org/10.26832/24566632.2019.0402015

\section{INTRODUCTION}

Weeds are considered to be as one of the major limiting factors due to manifold harmful effects (Kalyanasundaram et al., 2006) and weeds inflict negative effect on crop yield either competition for water or nutrients or space or light (Reddy and Reddi, 2011). Herbicides are effective in controlling weeds alone or in combination with hand weeding (Ahmed et al., 2014). Herbicides are used successfully for weed control in rice field for rapid effect, easier to application and low cost involvement in comparison to the traditional method of hand weeding (Sathyamoorthy et al., 2004). The environmental fate of herbicides is a matter of recent concern given that only a small fraction of the chemicals reach the target organisms (Pimentel, 1995), leading to poten- tial impacts of residual herbicides in soil and water have on human, animal and crop health. Bunce (1993) wrote in 1993 "It is useful to keep in mind the concept that a pollutant is a substance in the wrong place, at the wrong time, or in the wrong amount". While herbicides are very important to agriculture, under certain circumstances they may act as pollutants that can deteriorate soils, ground waters and surface waters. Soil biochemical and biological processes are critical for ecosystems functioning, as microbes have key roles in organic matter transformations, nutrient cycling and degradation of organic pollutants, including pesticides (Beck et al., 2005). Biological degradation mediated by microbial enzymes is the main route for pesticides detoxification in soils (Van Eerd et al., 2003). Depending upon the specific mode of action at work, it may involve a plant 
enzyme or a biological system that the herbicide may interrupt, thus injuring or disrupting the regular plant growth and development and causing eventual plant death (Shariq et al., 2015). Most isolated herbicide-degrading microorganisms belong to bacterial species, but fungi are also well-known for their capacity to degrade complex substrates, and may be more important than present isolation approaches have suggested (Smith and Collins, 2007). Herbicides can indirectly affect populations of birds, mammals, insects, and other animals through changes in the nature of their habitat (Hossain, 2015). Herbicides may also cause changes in microbial community function and concomitant impacts on soil health and ecosystem processes. Even though functions may appear unaltered, due to species redundancy in soil, the extinction of resistant species may compromise the continuity of such processes (Zabaloy et al., 2010). Sondhia (2014) found that increasing incidences of intentionally acute poisoning by some of the herbicide such as butachlor, fluchloralin, paraquat, 2,4-D, pendimethalin, glyphosate etc. are emerging problem in India.

Herbicide application in rice field is not a new concept in the world context but for Bangladesh farmers', especially the farmers in the central-north of Bangladesh, it is rather a new technology for controlling the weeds in the rice field. Different agro based companies in Bangladesh are producing or importing different kinds of herbicide with different degrees of toxicity having both residual and non-residual effect on soil environment. These companies are trying to motivate the local farmers to apply these herbicides in their rice field and some farmers are doing so. Though the farmers only know that there would be an easy removal of weed from the rice field but most of the cases they are not concerned about the negative impact of these herbicides on the soil and water quality of rice field. Therefore, present research is aimed to find out the farmers perception about the herbicides and their impact on soil environment of rice field, especially the availability of soil nutrients and water quality of rice field after application of herbicides.

\section{MATERIALS AND METHODS}

The study was conducted in two phases:

\section{Phase I}

Present status of using herbicides in rice cultivation

Before starting the field experiment, the information from farmer's level regarding herbicides use was collected from different villages of Mymensingh district. The data were collected by personal interview using a semi-structrued questionnaire, Group discussion etc. The data were collected mainly from farmer and the herbicide dealers in the respected area. After the collection of information, a list of the most frequently used herbicide by farmers were made and among which top two herbicides used by the local farmers were selected for field experiment. The top two herbicides were i. Laser (Pyrazosulphuron ethyl-10 WP) and ii. Changer (Acetachlor$14 \%+$ Bensulfuron methyl-4\%).
Phase II

\section{Field experiment}

\section{Experimental site}

The experiment was conducted at Agronomy Field Laboratory, Bangladesh Agricultural University, Mymensingh. The experiment consists of two factors i.e. Factor A: Crop (2) i. Rice crop $\left(C_{1}\right.$ and ii. No crop $\left(C_{0}\right)$; Factor B: Herbicides (3) i. No herbicide (control) $\left(\mathrm{H}_{0}\right)$, ii. Pyrazosulphuron ethyl $\left(\mathrm{H}_{1}\right)$ and iii. Acetachlor$14 \%+$ Bensulfuron methyl-4\% $\left(\mathrm{H}_{2}\right)$. The experiment was conducted following randomized complete block design (RCBD) with three replication and thus the total number of plots were $18(2 \times 3 \times 3)$. The size of the each plot was $10 \mathrm{~m}^{2}$.

\section{Soil sample collection}

The first batch of soil sample was collected before application of herbicide. Again soil sample from each plot were collected at 30 Days after transplanting and final batch of soil sample were collected after harvesting of rice. All the samples were collected maintaining proper procedure of soil sample collection.

\section{Chemical analysis of soil sample}

After collection, chemical analysis of the soil samples were done in Soil Resource Development Institute (SRDI), Dhaka for the following nutrient elements viz., $\mathrm{pH}$, chlorine, nitrogen (Total $\mathrm{N} \%$ ), phosphorus ( $\mu \mathrm{g} / \mathrm{g}$ soil), potassium (meq/100g soil), sulphur ( $\mu \mathrm{g} / \mathrm{g}$ soil), boron ( $\mu \mathrm{g} / \mathrm{g}$ soil), zinc ( $\mu \mathrm{g} / \mathrm{g}$ soil), microbial activity (CFU/ml) following standard methods (Chaturvedi and Sankar, 2006).

\section{Water sample collection}

The water sample from the rice field was collected in a regular interval (6 times). After transplanting of rice seedlings in the main field, the first batch of water sample were collected at the very first day of herbicide application in the rice field. The second, third, fourth, fifth and sixth batches of water sample will be collected at $3,5,10,20$ and 30 days after application of herbicide in the rice field.

\section{Chemical analysis of water sample}

After collection, chemical analysis of the water samples were done in Soil Resource Development Institute (SRDI), Dhaka for the following nutrient elements viz., $\mathrm{pH}, \mathrm{DO}$ (Dissolved oxygen), BOD (Biological oxygen demand), TDS (Total dissolved solid), chlorine, phosphorus ( $\mu \mathrm{g} / \mathrm{g}$ soil), potassium (meq/100g soil), sulphur ( $\mu \mathrm{g} / \mathrm{g}$ soil), boron ( $\mu \mathrm{g} / \mathrm{g}$ soil), zinc ( $\mu \mathrm{g} / \mathrm{g}$ soil) and microbial activities (CFU/ml) following standard methods (APHA, 2012).

\section{RESULTS AND DISCUSSION}

\section{Present status of herbicide use in the study area}

In the study area the local farmers are using herbicide to control weeds for the last few years (5-7 years). Before that they used to do it by hand pulling or Japanese rice weeder. However, usually they apply herbicide in the rice field three to five days after 
transplantation of rice seedlings. There are several types of herbicides found in the local market namely Laser (Pyrazosulfuron ethyl), Changer (Acetachlor + Bensulfuron methyl), Ronstar (oxadiazon), Granite (penoxsulam) etc. of which Laser (Pyrazosulfuron ethyl) and Changer (Acetachlor + Bensulfuron methyl) were extensively used by almost $85 \%$ of the local farmers. The interview with the herbicide users revealed that the farmers tried to follow the recommended dose of herbicide but sometimes they go for overdoses which cause a degradation of water quality.

Soil quality parameters as affected by herbicide application From the table 1 it can be found that before application of herbicide in the rice field the $\mathrm{pH}$ of the soil was 6.3 and after the application of herbicide in both crop (rice) field and non-crop field the $\mathrm{pH}$ value did not changed significantly and the range was 6.0-6.3. For the total nitrogen (\%), it was also not affected by the herbicide application, though numerically higher amount of total nitrogen was found in non-cropped field soil than that of

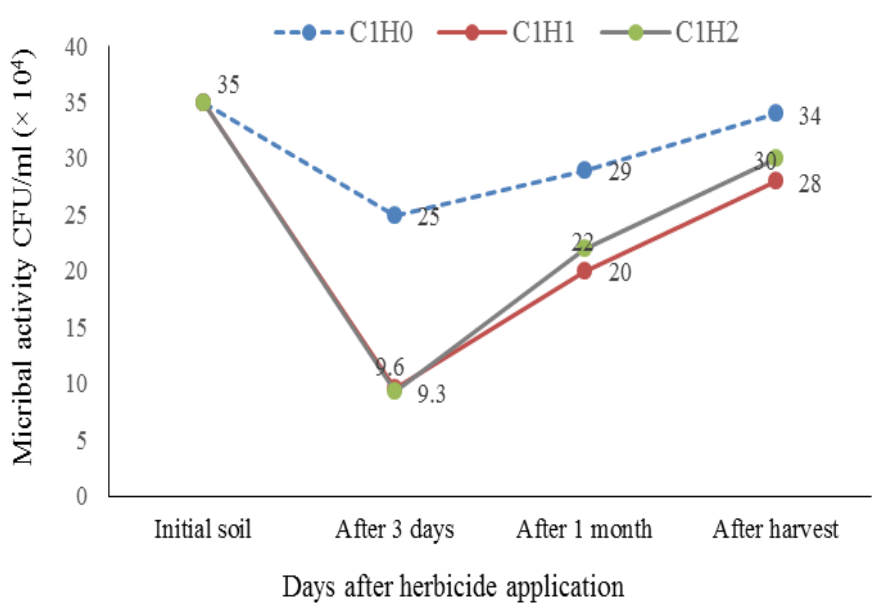

Figure 1. Effect of herbicide on microbial activity in rice field soil. cropped field soil in both types of herbicide applied field (Table 1). Potassium content of the soil did not changed significantly after application of herbicide in the rice field. For phosphorus, though the content was higher (3.19 ppm) in initial soil but it was found that after harvesting of the rice crop the phosphorus content became lower than that of initial soil. It has been also noticed that the phosphorus content after harvest was found less in herbicide applied soil than that of no herbicide applied soil in both cropped and non-cropped field (Table 1). In case of Sulphur content, higher amount of Sulphur was found after one month of rice transplantation than that of initial soil. This might be due to the residual effect of Sulphur that has been applied as basal dose as gypsum during final land preparation. Also both the herbicide applied in the rice field has Sulphur content in their chemical composition. Application of herbicide was found a cause of declining boron content in the rice field. It has been found that in the herbicide applied field the content of boron in soil was less than the plot where herbicide was not applied.

Zinc was found a little bit higher in the initial soil though the content did not change much after the application of herbicide in the field both in cropped and non-cropped field. Herbicide application showed changes in chlorine content in the soil. It has been found that initially the chlorine content was $35.5 \mathrm{ppm}$ in the soil which was found higher in the plots where herbicide 2 (acetachlor and bensulfuron methyl) was applied (Table 1). This might be due to the chemical composition of that particular herbicide that contains chlorine. Regarding microbial activity in the soil after application of herbicide it has been found that the number of microbes was $35 \times 10^{4}$ colony forming unit (cfu/ml) (Figure 1) which was sharply declined after 3 days of herbicide application (for both the herbicides) than that of no herbicide applied soils. Though with the time the microbial activities increased to a level similar to the initial soil. This might be due to the self-degradation of herbicides over time.

Table 1. Different soil quality parameters as affected by herbicide application in the rice field.

\begin{tabular}{|c|c|c|c|c|c|c|c|c|c|}
\hline \multirow[b]{2}{*}{ Treatments } & & \multicolumn{8}{|c|}{ Mean value of soil quality parameters } \\
\hline & & $\mathrm{pH}$ & $\begin{array}{c}\text { Total N } \\
(\%)\end{array}$ & $\begin{array}{l}\mathrm{K} \text { (meq/100g } \\
\text { soil) }\end{array}$ & $\underset{(p p m)}{P}$ & $\underset{(p p m)}{S}$ & $\begin{array}{c}\mathrm{B} \\
(\mathrm{ppm})\end{array}$ & $\underset{(p p m)}{Z n}$ & $\begin{array}{c}\mathrm{Cl} \\
(\mathrm{ppm})\end{array}$ \\
\hline \multirow[t]{3}{*}{ Initial soil } & & 6.3 & 0.120 & 0.11 & 3.19 & 9.69 & 0.27 & 2.05 & 35.5 \\
\hline & $\mathrm{C}_{0} \mathrm{H}_{0}$ & 6.3 & 0.155 & 0.11 & 2.43 & 26.35 & 0.16 & 1.42 & 36.5 \\
\hline & $\mathrm{C}_{0} \mathrm{H}_{1}$ & 6.2 & 0.151 & 0.11 & 3.01 & 26.21 & 0.03 & 1.50 & 35.8 \\
\hline \multirow{6}{*}{$\begin{array}{l}\text { After one month of rice } \\
\text { transplantation }\end{array}$} & $\mathrm{C}_{0} \mathrm{H}_{2}$ & 6.2 & 0.156 & 0.10 & 2.30 & 12.47 & 0.02 & 1.13 & 42.5 \\
\hline & $\mathrm{C}_{1} \mathrm{H}_{0}$ & 6.1 & 0.115 & 0.10 & 2.11 & 24.85 & 0.17 & 1.44 & 29.7 \\
\hline & $\mathrm{C}_{1} \mathrm{H}_{1}$ & 6.0 & 0.132 & 0.09 & 2.59 & 21.45 & 0.05 & 1.61 & 30.5 \\
\hline & $\mathrm{C}_{1} \mathrm{H}_{2}$ & 6.2 & 0.084 & 0.10 & 2.50 & 19.21 & 0.01 & 1.28 & 40.6 \\
\hline & $\mathrm{C}_{0} \mathrm{H}_{0}$ & 6.1 & 0.108 & 0.09 & 0.57 & 8.84 & 0.12 & 1.68 & 32.5 \\
\hline & $\mathrm{C}_{0} \mathrm{H}_{1}$ & 6.1 & 0.104 & 0.10 & 0.35 & 10.30 & 0.07 & 1.86 & 32.8 \\
\hline \multirow{4}{*}{ After harvest } & $\mathrm{C}_{0} \mathrm{H}_{2}$ & 6.2 & 0.104 & 0.11 & 0.36 & 5.78 & 0.05 & 1.68 & 40.5 \\
\hline & $\mathrm{C}_{1} \mathrm{H}_{0}$ & 6.0 & 0.061 & 0.09 & 0.53 & 5.57 & 0.15 & 1.97 & 28.7 \\
\hline & $\mathrm{C}_{1} \mathrm{H}_{1}$ & 6.1 & 0.098 & 0.08 & 0.26 & 6.80 & 0.05 & 1.98 & 28.5 \\
\hline & $\mathrm{C}_{1} \mathrm{H}_{2}$ & 6.9 & 0.051 & 0.09 & 0.42 & 3.39 & 0.09 & 1.66 & 34.6 \\
\hline
\end{tabular}

$\mathrm{C}_{0}=$ No rice crop, $\mathrm{C}_{1}=$ With rice crop; $\mathrm{H}_{0}=$ No herbicide application, $\mathrm{H}_{1}=$ Pyrazosulfuron ethyl, $\mathrm{H}_{2}=$ Acetachlor + Bensulfuron methyl. 


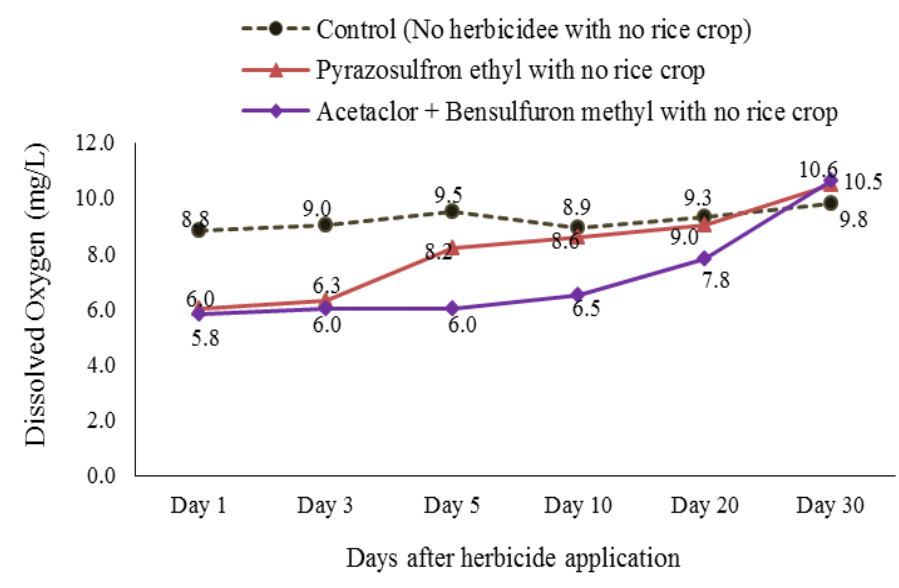

Figure 2. Effect of herbicide on dissolved oxygen (DO) at different days after application.

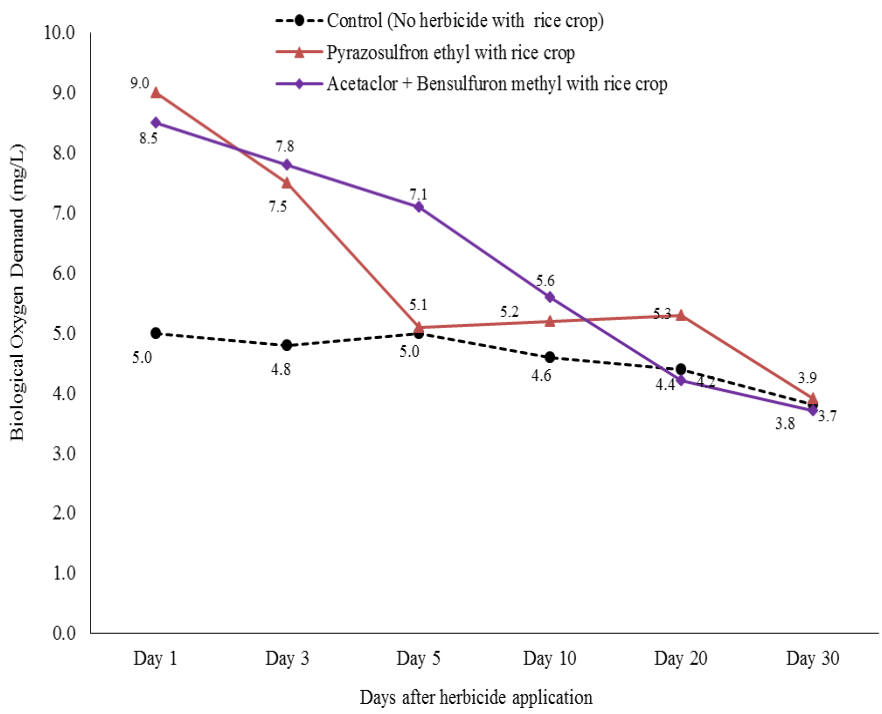

Figure 3. Effect of herbicide on biological oxygen demand (BOD) at different days after application.

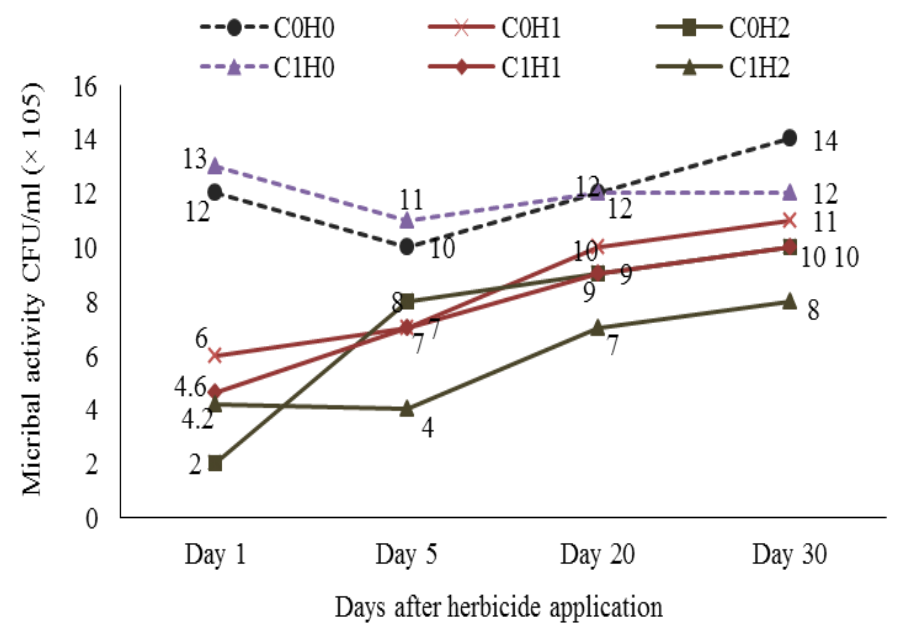

Figure 4. Effect of herbicide on microbial activity in rice field water.

Water quality parameters as affected by herbicide application Effect of herbicide application on dissolved oxygen of rice field water is shown in the Figure 2. It has been seen from the figure that the amount of dissolved oxygen in no herbicide applied plots was in a similar trend throughout the data collection time. But in the herbicide applied rice plots, it is seen that just one day after application of herbicide (for both Pyrazosulfuron and Acetaclor + Bensulfuron methyl) the dissolved oxygen has been reduced to a significant amount compared to no herbicide applied plots. Though after 30 days of herbicide application the amount of dissolved oxygen in all the herbicide applied plots and no herbicide applied plots were found almost similar (Figure 2). Figure 3 shows the relationship between biological oxygen demand and herbicide application in the rice field. It has been found that the BOD was high at the very early stage of herbicide application ( 1 day after application) in the rice field for both the herbicides (for pyrazosulfuron ethyl it is $9.0 \mathrm{mg} / \mathrm{L}$ and for acetaclor + bensulfuron methyl it is $8.5 \mathrm{mg} / \mathrm{L}$ ) compared to no herbicide applied plots. Gradually the BOD was declined over the time and it was found that after 30 days of herbicide application the herbicide applied and no herbicide applied plots got almost similar BOD. Microbial activity in rice field water after application of herbicide has been shown in Figure 4. It has been found that after one day of herbicide application the number of colony forming unit (cfu/ml water) has been declined to a range of $2 \times 10^{5}$ to $6 \times 10^{5}$ compared to the no herbicidal applied plots where the cfu was $12 \times 10^{5} / \mathrm{ml}$ where rice crop was grown and $13 \times 10^{5}$ where rice crop was not grown. Though in all the plots where herbicide was applied the microbial activity again increased with the increasing of time (Figure 4). This is an indication that just after the application of herbicide in the rice field, initially the microbial activity is reduced and with the time microbial activity regain. This could hamper the initial growth of the rice plant as the declined microbial activity may cause a lower level of mineralization of organic matter or applied fertilizer in the rice field. Thus, the young rice plant may suffer from malnutrition and hence tend to decrease the grain yield.

Status of $\mathrm{pH}$ and total dissolved solid (TDS) in rice field water after application of herbicide is presented in Table 2. It has been found that the $\mathrm{pH}$ value did not change throughout the rice production period even in herbicide applied and no herbicide applied plots. The amount of total dissolved solid did not change significantly. Considering the other nutrient elements potassium, phosphorus, boron and zinc were not found significantly changed (Table 3), though there were a fluctuation in sulfur content of rice field water was found throughout the data collection period. However, in case of chlorine content, it can be seen from the table 3 that initially chlorine content in the no herbicide applied no rice plot was found $35.0 \mathrm{ppm}$ which was almost similar even when the sample was collected 30 days after herbicide application in the field. But the chlorine content was found much higher (49.0 ppm) in the plots where herbicide 2 (Acetachlor + Bensulfuron methul) was applied and the amount was not changed significantly even when the data were again collected after 30 days. This might be due to no rice plant in the plots to uptake chlorine. However, in the plots where rice was transplanted the initial chlorine content in the no herbicide applied plots were similar to those plots where rice was not transplanted, but higher amount of chlorine was found (48.5 $\mathrm{ppm}$ ) in the plots where herbicide 2 (Acetachlor + Bensulfuron methul) was applied and the amount was decreased at the later stage (after 30 days of herbicide application). This might be due to the uptake of chlorine by the rice plants. 
Table 2. Status of $\mathrm{pH}$ and total dissolved solid (TDS) of rice field water after application of herbicides.

\begin{tabular}{lcccccccc}
\hline \multirow{2}{*}{ Treatments } & \multicolumn{9}{c}{$\mathbf{p H}$} & \multicolumn{3}{c}{ TDS (ppt) } \\
\cline { 2 - 10 } & Day 1 & Day 5 & Day 20 & Day 30 & Day 1 & Day 5 & Day 20 & Day 30 \\
\hline $\mathrm{C}_{0} \mathrm{H}_{0}$ & 7.7 & 8.2 & 8.2 & 8.3 & 0.16 & 0.10 & 0.07 & 0.15 \\
$\mathrm{C}_{0} \mathrm{H}_{1}$ & 8.2 & 8.9 & 8.4 & 8.2 & 0.19 & 0.10 & 0.09 & 0.16 \\
$\mathrm{C}_{0} \mathrm{H}_{2}$ & 8.1 & 8.4 & 8.4 & 8.4 & 0.18 & 0.16 & 0.06 & 0.22 \\
$\mathrm{C}_{1} \mathrm{H}_{0}$ & 8.4 & 8.2 & 8.2 & 8.3 & 0.15 & 0.11 & 0.07 & 0.17 \\
$\mathrm{C}_{1} \mathrm{H}_{1}$ & 8.6 & 8.2 & 8.1 & 8.2 & 0.16 & 0.11 & 0.08 & 0.18 \\
$\mathrm{C}_{1} \mathrm{H}_{2}$ & 9.0 & 8.1 & 8.3 & 8.3 & 0.14 & 0.13 & 0.08 & 0.18 \\
\hline
\end{tabular}

Table 3. Water quality parameters of rice field at different days after application of herbicide.

\begin{tabular}{|c|c|c|c|c|c|c|c|c|c|c|c|c|}
\hline \multirow{2}{*}{ Treatments } & \multicolumn{4}{|c|}{ Potassium (ppm) } & \multicolumn{4}{|c|}{ Phoshorus (ppm) } & \multicolumn{4}{|c|}{ Sulfur (ppm) } \\
\hline & Day 1 & Day 5 & Day 20 & Day 30 & Day 1 & Day 5 & Day 20 & Day 30 & Day 1 & Day 5 & Day 20 & Day 30 \\
\hline $\mathrm{C}_{0} \mathrm{H}_{0}$ & 0.013 & 0.006 & 0.005 & 0.005 & 1.580 & 1.210 & 0.730 & 2.040 & 4.040 & 2.510 & 9.110 & 8.900 \\
\hline $\mathrm{C}_{0} \mathrm{H}_{1}$ & 0.014 & 0.007 & 0.006 & 0.005 & 2.120 & 2.010 & 0.610 & 1.360 & 5.160 & 6.420 & 6.960 & 9.860 \\
\hline $\mathrm{C}_{0} \mathrm{H}_{2}$ & 0.013 & 0.009 & 0.006 & 0.005 & 3.110 & 1.630 & 0.550 & 0.660 & 2.340 & 2.310 & 5.120 & 8.870 \\
\hline $\mathrm{C}_{1} \mathrm{H}_{0}$ & 0.013 & 0.007 & 0.004 & 0.005 & 3.070 & 1.710 & 0.710 & 0.810 & 8.220 & 5.200 & 25.740 & 5.400 \\
\hline $\mathrm{C}_{1} \mathrm{H}_{1}$ & 0.015 & 0.007 & 0.005 & 0.005 & 5.290 & 1.610 & 0.650 & 0.930 & 2.880 & 8.050 & 36.210 & 8.900 \\
\hline $\mathrm{C}_{1} \mathrm{H}_{2}$ & 0.012 & 0.007 & 0.004 & 0.006 & 1.500 & 1.010 & 1.220 & 0.760 & 2.850 & 8.050 & 16.520 & 7.820 \\
\hline \multirow{2}{*}{ Treatments } & \multicolumn{4}{|c|}{ Boron (ppm) } & \multicolumn{4}{|c|}{ Zinc (ppm) } & \multicolumn{4}{|c|}{ Chlorin (ppm) } \\
\hline & Day 1 & Day 5 & Day 20 & Day 30 & Day 1 & Day 5 & Day 20 & Day 30 & Day 1 & Day 5 & Day 20 & Day 30 \\
\hline $\mathrm{C}_{0} \mathrm{H}_{0}$ & 0.060 & 0.050 & 0.020 & 0.030 & 0.008 & 0.008 & 0.008 & 0.009 & 35.0 & 36.0 & 34.5 & 34.5 \\
\hline $\mathrm{C}_{0} \mathrm{H}_{1}$ & 0.080 & 0.030 & 0.010 & 0.060 & 0.009 & 0.008 & 0.008 & 0.009 & 36.0 & 35.5 & 35.0 & 35.5 \\
\hline $\mathrm{C}_{0} \mathrm{H}_{2}$ & 0.050 & 0.030 & 0.050 & 0.050 & 0.006 & 0.006 & 0.010 & 0.008 & 49.0 & 48.0 & 47.5 & 47.0 \\
\hline $\mathrm{C}_{1} \mathrm{H}_{0}$ & 0.040 & 0.040 & 0.010 & 0.020 & 0.009 & 0.007 & 0.008 & 0.008 & 35.5 & 35.5 & 33.0 & 32.0 \\
\hline $\mathrm{C}_{1} \mathrm{H}_{1}$ & 0.030 & 0.060 & 0.050 & 0.010 & 0.009 & 0.007 & 0.010 & 0.008 & 35.0 & 34.5 & 33.5 & 30.0 \\
\hline $\mathrm{C}_{1} \mathrm{H}_{2}$ & 0.010 & 0.060 & 0.070 & 0.010 & 0.008 & 0.009 & 0.010 & 0.009 & 48.5 & 45.5 & 42.0 & 40.0 \\
\hline
\end{tabular}

Conclusion

Based on the findings, it is found that local farmers of the Mymensingh region in Bangladesh used to apply two types of herbicide (i. Pyrazosulphuron ethyl-10 WP and ii. Acetachlor$14 \%+$ Bensulfuron methyl-4\%) in their rice field. Sometimes they used to apply more than the recommended dose to get desirable destruction level of weed. Considering the experimentation with that herbicide it has been found that the application of herbicide in the rice field does not change the nutrient content in the soil or water of rice field. But herbicide significantly reduces the microbial activity in both soil and water of rice field. In case of herbicide 2 i.e. Acetachlor-14\% + Bensulfuron methyl$4 \%$, it increases the chlorine content in the both soil and water and thus the presence of this high amount of $\mathrm{Cl}$ content in the rice field may cause burning injury of rice leaf which could affect the yield of rice.

\section{ACKNOWLEDGEMENT}

The Principal investigator is thankful to the University Grants Commission for providing the grant (6(78)/UGC/Crop$18 / 2016 / 5714)$ that really helped the research.

Open Access: This is an open access article distributed under the terms of the Creative Commons Attribution 4.0 License, which permits unrestricted use, distribution, and reproduction in any medium, provided the original author(s) if the sources are credited.

\section{REFERENCES}

Ahmed, M.R., Bari, M.N., Haque, M.M. and Rahman, G.K.M.M. (2014). Effect of herbicide dose and water management on weed control efficiency and yield performance of boro rice. Journal of Science Foundation, 12 (2): 39-46, https://doi.org/10.3329/jsf.v12i2.27737

APHA. (2012). Standard methods for the examination of water and waste water, $21^{\text {st }}$ Edn. American Public Health Association, Washington pp. 2462.

Beck, L., Römbke, J., Breure, A.M. and Mulder, C. (2005). Considerations for the use of soil ecological classification and assessment concepts in soil protection. Ecotoxicology and Environmental Safety, 62(2): 189-200, https://doi.org/10.1016/j.ecoenv.2005.03.024

Bunce, N.J. (1993). Introduction to Environmental Chemistry, Wuerz Publishing Ltd., Winnipeg, Canada.

Chaturvedi, R.K and Sankar, K. (2006). Laboratory manual for the physicochemical analysis of soil, water and plant. Wildlife Institute of India, Dehradun.

Hossain, M.M. (2015). Recent perspective of herbicide: Review of demand and adoption in world agriculture. Journal of Bangladesh Agricultural University, 13 (1):19-30.

Kalyanasundaram, D., Kumar, S.R.V. and Kumar, K.P.S. (2006). Studies on integrated weed management indirect-seeded lowland rice (Oryza sativa L.). Journal of Research on Crops, 7 (3): 627-629.

Pimentel, D. (1995). Amounts of pesticides reaching target pests: Environmental impacts and ethics. Journal of Agricultural and Environmental Ethics, 8: 17-29.

Reddy, T.Y. and Reddi, G.H.S. (2011). Principles of Agronomy. Kalyani Publishers, Noida, India. pp. 527.

Sathyamoorthy, N.K., Mahendran, S., Babu, R. and Ragavan, T. (2004). Effect of integrated weed management practices on total weed dry weight, nutrient removal of weeds in rice-rice wet seedbed system. Journal of Agronomy, 3(4): 263-267, https://doi.org/10.3923/ja.2004.263.267

Shariq, I.S., Ibrahim, A.A. and Haseeb, A.K. (2015). Modes of action of different classes of herbicides. herbicides, physiology of action and safety. Andrew Price, Jessica Kelton and Lina Sarunaite, Intech Open, https://doi.org/10.5772/61779 
Smith, J. L. and Collins, H. P. (2007). Management of organisms and their processes in soils, in E. A. Paul (ed.), Soil Microbiology, Ecology and Biochemistry, Academic Press, Oxford, UK, pp. 471-502.

Sondhia, S. (2014). Herbicides residues in soil, water, plants and non-targeted organisms and human health implications: an Indian perspective. Indian Journal of Weed Science, 46(1): 66-85, http://isws.org.in/IJWSn/File/2014_46_Issue-1_66-85.pdf

Van Eerd, L.L., Hoagland, R.E., Zablotowicz, R. M. and Hall, J. C. (2003). Pesticide metabolism in plants and microorganisms. Weed Science, 51: 472-495, https://doi.org/10.1614/0043-1745(2003)051[0472:PMIPAM] 2.0.CO;2

Zabaloy, M.C., Garland, J.L. and Gómez, M.A. (2010). Assessment of the impact of 2,4- dichlorophenoxyacetic acid (2,4-D) on indigenous herbicidedegrading bacteria and microbial community function in an agricultural soil. Applied Soil Ecology, 46: 240-246, https://doi.org/10.1016/j.apsoil.2010.08.006 